\title{
Studi Analisis Fasilitas Jembatan Penyeberangan Orang di Kota Tarakan
}

\author{
Daud Nawir ${ }^{1}$, Rusmiyanti ${ }^{2}$ \\ 1,2Jurusan Teknik Sipil, Universitas Borneo Tarakan \\ E-mail: 1daudnawir@gmail.com
}

Received 08 April 2019; Reviewed 11 Mei 2019; Accepted 29 Mei 2019

http://jurnal.borneo.ac.id/index.php/borneoengineering

\begin{abstract}
The provision of crossing facilities which is a Pedestrians Bridge In Tarakan city, was first built. This research was to aim of knowing the crossing facilities that are in accordance with the location conditions of the research study, both technically and in a special standard design, knowing the level of performance of the Pedestrians Bridge Facility for pedestrians. Data analysis of the number of vehicle volumes $(V)$ is 5126 vehicles / hour and pedestrian volume $(P)$ is 66 people / hour using the PV 2 formula 1728882386.2. Through Determination of crossing facilities on Yos Sudarso, in front of Grand Tarakan Mall, only requires Pelican with a protector or Pelican Crossing along with a waiting stall that has the criteria for the number $P=50-1100$ people / hour, $V>700$ vehicles / hour and PV2 > 2x10 8. For the bridge design, found on the standard for building stair height, did not meet the standards, which was 1.35 meters, while the height of the backrest in the field was 1.15 - 1.20 meters. The level of The Pedestrian Bridge use was $68.77 \%$ and could be stated as beneficial. The results of the questionnaire were obtained on the Cartesian diagram in quadrant 1, which is the main priorities that must be improved in the Pedestiran Bridge services are the ease of access for persons with disabilities and the hygiene care of the Pedestrian Bridge's facilities.
\end{abstract}

Keywords: Pedestrians, Crossing Facilities, Cartesian Diagram.

\begin{abstract}
Abstrak
Penyediaan fasilitas penyeberangan berupa Jembatan Penyeberangan Orang (JPO) Di Kota Tarakan baru pertama kali dibangun. Penelitian ini dilaksanakan dengan tujuan mengetahui fasilitas penyeberangan yang sesuai dengan kondisi lokasi studi penelitian, baik secara teknis maupun secara desain standart khusus,mengetahui tingkat kinerja dari fasilitas jembatan penyeberangan orang (JPO) bagi pejalan kaki. Analisis data jumlah volume kendaraan (V) sebesar 5126 kendaraan/jam dan volume pejalan kaki (P) sebesar 66 orang/jam menggunakan rumus PV2 yaitu 1728882386.2. Dengan Penentuan fasilitas penyeberangan di jalan Yos Sudarso depan GTM hanya memerlukan pelican dengan pelindung atau Pelican Crossing dengan lapak tunggu yang memiliki kriteria jumlah $\mathrm{P}=50-1100$ orang/jam, $\mathrm{V}>700 \mathrm{kend} / \mathrm{jam}$ dan nilai PV2 >2 x 108. Untuk desain jembatan didapatkan pada standar pembangunan tinggi sandaran anak tangga tidak memenuhi standar yang ditentukan yaitu 1.35 meter, sedangkan tinggi sandaran anak tangga di lapangan berukuran 1.15 - 1.20 meter. Tingkat penggunaan JPO sebesar $68,77 \%$ dan dapat dinyatakan bermanfaat. Hasil dari kuisioner didapatkan pada diagram kartesius dalam kuadran 1 yaitu prioritas utama yang harus ditingkatkan pada pelayanan JPO adalah mudah diakses oleh penyandang disabilitas dan kebersihan fasilitas JPO.
\end{abstract}

Kata Kunci : Pejalan kaki, Fasilitas Penyeberangan, Diagram Kartesius. 


\section{Pendahuluan}

Kota Tarakan adalah sebuah kota di Kalimantan Utara, Indonesia dan juga merupakan kota terbesar di Kalimantan Utara dan akan terus bertambah jumlah penduduknya, Kota ini memiliki luas wilayah $250,80 \mathrm{~km}^{2}$ dan sesuai dengan data Dinas Kependudukan dan Pencatatan Sipil (Disdukcapil) Kota Tarakan mencatat, data kependudukan sampai bulan November 2016 sebanyak 247.186 jiwa. Peningkatan jumlah pergerakan ditandai dengan meningkatnya volume lalu lintas kendaraan maupun volume pejalan kaki pada suatu ruas jalan perkotaan . Di Kota Tarakan, Penyediaan fasilitas penyeberangan berupa Jembatan Penyeberangan Orang (JPO) baru pertama kali dibangun. Pada pembanguan fasilitas ini menghabiskan dana sebesar Rp 2.549.674.000,00 dan waktu pelaksanaan pekerjaan kurang lebih 5 bulan terhitung mulai bulan Oktober 2017. Dengan biaya pembanguan yang cukup besar diharapkan keberadaan JPO pun digunakan sesuai dengan fungsinya dan dapat mengurangi tingkat kemacetan, kecelakaan lalu lintas, keselamatan bagi para pejalan kaki akibat adanya pertemuan antara pengguna jalan (kendaraan) dengan pejalan kaki yang melintas di atas jalan raya serta pemanfaatan jembatan penyebrangan juga harus tetap pada fungsinya.

Pada penelitian sebelumnya yaitu Pranata (2017) dengan judul "Evaluasi Efektivitas Dan Kelayakan Teknis Jembatan Penyeberangan Orang (Jpo) Di Cbd Kota Bandar Lampung". Dari hasil analisis (nilai P, V, dan PV2), berdasarkan pada tabel, kedua JPO yang berada di jl. Kartini cukup baik ditempatkan pada lokasi tersebut. Efektivitas pada JPO lokasi satu dan lokasi dua jl. Kartini masing - masing 61,1543\% dan 33,2538\% pada hari libur dan 66,8144\% serta 37,0530\% pada hari kerja. Berdasarkan analisis kuisioner, responden memilih menggunakan JPO sebesar $90 \%$ pada lokasi satu dan 94\% pada lokasi dua. Faktor yang mempengaruhi dari efektivitas JPO yang berada di jl. Kartini yang perlu jadi perhatian adalah kebersihan yang berada pada Kuadran I Prioritas Utama. Penelitian sebelumnya juga dilakukan oleh Idris (2007) dengan judul "Jembatan Penyeberangan di Depan Kampus UMS Sebagai Fasilitas Pejalan Kaki"Jembatan penyeberangan yang terletak di depan kampus UMS dirancang untuk fasilitas penyeberangan umum, terutama untuk UMS civitas academica. Hasil analisis menunjukkan P.V $>$ 2,998 x 109 dengan jumlah pejalan kaki yang melintasi jembatan 303 orang / jam dan tingkat lalu lintas 3146 kendaraan / jam.

Pada penelitian ini menggunakan metode IPA (Importance Performance Analysis) yaitu untuk mengetahui faktor-faktor apa saja yang dapat mempengaruhi penggunaan pada fasilitas penyeberagan seperti jembatan penyeberangan orang di jalan Yos Sudarso depan GTM (Grand Tarakan Mall) di Kota Tarakan. Tujuan dari penelitian yang dilakukan yaitu mengetahui fasilitas penyeberangan yang sesuai dengan kondisi lokasi studi penelitian, mengetahui kesesuaian kriteria pembangunan JPO dengan aturan perencanaan JPO, dan mengetahui tingkat kinerja dari fasilitas Jembatan Penyeberangan Orang (JPO) bagi pejalan kaki.

\section{Tinjauan Pustaka}

\subsection{Fasilitas penyeberangan}

Dalam Tata Cara Perencanaan Fasilitas Pejalan Kaki di Kawasan Perkotaan No. 011/T/Bt/1995 Tahun 1995ada 2 jenis pengelompokkan fasilitas penyeberangan sebagai berikut:

\subsubsection{Penyeberangan sebidang}

Ada babarapa jenis penyeberangan sebidang yaitu zebra cross tanpa atau dengan pelindung dan pelikan tanpa atau dengan pelindung. Penyeberangan tanpa pelindung adalah penyeberangan yang tidak dilengkapi dengan pulau pelindung. Sedangkan penyeberangan dengan pelindung adalah penyeberangan yang dilengkapi dengan pulau pelindung dan rambu peringatan awal bangunan pemisah untuk lalu lintas dua arah. 
Kriteria dalam memilih fasilitas penyeberangan sebidang didasarkan pada rumus empiris $\mathrm{PV}^{2}$, dengan $\mathrm{P}$ adalah arus lalu lintas penyeberang jalan yang menyeberang jalur lalu lintas sepanjang 100 meter, dinyatakan dengan pejalan kaki/jam. $\mathrm{V}$ adalah arus lalu-Iintas dua arah per jam, dinyatakan dalam kendaraan/jam.Nilai P dan V merupakan arus rata-rata pejalan kaki dan kendaraan dalam jamjam tersibuk.

\subsubsection{Penyeberangan tidak sebidang}

Jenis fasilitas penyeberangan tidak sebidang dapat berupa jembatan penyeberangan atau terowongan penyeberangan. Fasilitas ini ditempatkan pada ruas jalan yang memiliki kriteria sebagai berikut :

a. Pada ruas jalan dengan kecepatan rencana $>70 \mathrm{~km} / \mathrm{jam}$

b. Pada kawasan strategis, tapi para penyeberang jalan tidak memungkinkan.

c. Untuk menyeberang jalan, kecuali hanya pada jembatan penyeberangan.

d. $\quad \mathrm{PV}^{2}>2 \times 108$, dengan $: \mathrm{P}>1100$ orang/jam dan $\mathrm{V}>750 \mathrm{kend} / \mathrm{jam}$. Nilai $\mathrm{V}$ yang diambil adalah dari arus rata-rata selama 4 jam tersibuk.

\subsection{Ketentuan pembangunan jembatan penyeberangan pejalan kaki}

Menurut Tata Cara Perencanaan Jembatan Penyeberangan Untuk Pejalan Kaki di Perkotaan No. 027/T/Bt/1995 Tahun 1995, jembatan penyeberangan pejalan kaki adalah jembatan yang hanya diperuntukan bagi lalu lintas pejalan kaki yang melintas di atas jalan raya atau jalan kereta api. Pembangunan jembatan penyeberangan dibuat apabila memenuhi ketentuan sebagai berikut :

1. Bila zebra cross dan pelican cross mengganggu lalu lintas yang ada.

2. Pada ruas jalan terjadinya frekuensi kecelakaan yang melibatkan pejalan kaki tinggi.

3. Pada ruas jalan yang memiliki arus pejalan kaki yang tinggi serta arus kendaraan yang memiliki kecepatan tinggi.

4. Jembatan penyeberangan untuk pejalan kaki yang dibangun melintas diatas jalan raya atau jalur kereta yaitu pelaksanaanya cepat dan mudah, tidak mengganggu kelancaran lalu lintas.

5. Memenuhi tuntutan estetika dan keserasian dengan lingkungan dan sekitarnya, seperti jembatan penyeberangan yang melintas di atas jalan raya tangga dan kepala jembatan diletakkan di luar jalur trotoar, pilar tengah diletakkan di median.

\subsection{Tingkat pemanfaatan jembatan penyeberangan}

Penilaian tingkat pemanfaatan jembatan penyeberangan oleh pejalan kaki didasarkan pada hasil penelitian Hankin B.D., Wright R.A, 1958, dalam Rahmani, Hudan 2003 dan dikutip Mashuri 2012 seperti yang disajikan pada Tabel 1 berikut ini :

Tabel 1 Kriteria tingkat pemanfaatan jembatan penyeberangan

\begin{tabular}{cccc}
\hline No. & Tingkat pemanfaatan & \multicolumn{2}{c}{ Persentase jumlah pejalan kaki yang menyebrang } \\
\cline { 3 - 4 } & & $\begin{array}{c}\text { Memakai jembatan } \\
\text { penyeberangan }(\boldsymbol{\%})\end{array}$ & $\begin{array}{c}\text { Tidak memakai jembatan } \\
\text { penyeberangan }(\%)\end{array}$ \\
\hline $\mathbf{1}$ & Sangat Tidak Bermanfaat & $0-20$ & $100-80$ \\
$\mathbf{2}$ & Tidak bermanfaat & $21-40$ & $79-60$ \\
$\mathbf{3}$ & Cukup Bermanfaat & $41-60$ & $59-40$ \\
$\mathbf{4}$ & Bermanfaat & $61-80$ & $39-20$ \\
$\mathbf{5}$ & Sangat Bermanfaat & $81-100$ & $19-0$ \\
\hline
\end{tabular}

Sumber : Hankin B.D., Wright R.A, 1958 dalam Rahmani Hudan, 2003 dikutip Mashuri, 2012.

\subsection{Metode IPA (Importance-Perfomance Analysis)}

Dalam teknik menjelaskan konsep tentang loyalty pelanggan. Dari model ini dapat diketahui ada dua variabel utama yang menentukan kepuasan pelanggan yaitu expectation dan perceived 
performance.Expectation adalah harapan pelanggan terhadap produk yang diinginkan. Harapan ini dipengaruhi kebutuhan pribadi, pengalaman masa lalu, rekomendasi dari mulut ke mulut dan iklan. Sementara perceived performance adalah persepsi pelanggan terhadap penampilan, kinerja dari produk/produsen. Sehingga dapat disimpulkan bahwa importance performance analysis ini membandingkan antara expectation (harapan) dengan perceived performance (kinerja perusahaan) dalam mengukur kepuasan konsumen suatu perusahaan .

\section{Metode Penelitian}

\subsection{Tahap penelitian}

Merupakan survei awal untuk mengetahui kondisi lokasi fasilitas penyeberangan dengan melakukan pengamatan langsung kelokasi serta melakukan perhitungan volume kendaraan dan volume pejalan kaki. Dan penyebaran kuisioner tahap 1 yaitu untuk menguji validitas pertanyaan harapan / tingkat kepentingan dan pertanyaan penilaian kinerja jembatan penyeberangan orang di Jalan Yos Sudarso depan GTM (Grand Tarakan Mall) kota di Kota Tarakan.

\subsection{Sumber data}

Dalam penelitian ini dilakukan dengan menggunakan dua (2) jenis data yakni :

1. Data Primer

Data primer, yaitu data yang diperoleh langsung dari pengumpulan hasil survey atau pengamatan langsung di lokasi penelitian.

a. Volume kendaraan dan Volume Pejalan kaki

Pengambilan data volume kendaraan bersamaan dengan pengambilan volume pejalan kaki yang melewati JPO dan tidak melewati JPO. Dan untuk kendaraan yang melintasi jalan Yos Sudarso dalam 2 arah.

b. Desain JPO

Peneliti melakukan pengukuran dimensi dari JPO yang berada di Jl. Yos Sudarso di depan Grand Tarakan Mall (GTM) untuk mengetahui pembangunan JPO sudah dibangun sesuai dengan tatacara perencanaan jembatan penyeberangan untuk pejalan kaki di perkotaan.

c. Populasi

Populasi adalah pengguna fasilitas pejalan kaki yang melewati jembatan penyeberangan .

d. Sampel

Pengambilan sampel yang dilakukan dalam penilaian ini adalah nonprobability sampling dengan teknik sampling insidental dimana penelitian sampel berdasarkan kebetulan yaitu siapa saja pengguna yang melewati fasilitas penyebrangan pejalan kaki di jalan Yos Sudarso.

e. Penyebaran kuisioner

Pada Penyebaran kuisioner rumus Slovin dapat di pakai untuk menentukan ukuran sampel, penelitian bertujuan untuk yang menduga proposi populasi.

Rumus slovin adalah :

$$
n=\frac{N}{N x E^{2}+1}
$$

Keterangan :

$\mathrm{n} \quad=$ Banyaknya Responden (Ukuran Sampel)

$\mathrm{N} \quad=$ Banyaknya Anggota Populasi

E $\quad=$ Tingkat Kesalahan Sampel Yang Diharapkan

2. Data Sekunder

Data sekunder, yaitu data yang diperoleh dari skripsi yayan kusumawardana berjudul Pemetaan SIG. dan PT. Bumi Kaltara Konsultan yaitu Peta kota TarakanDesain Jembatan Penyeberangan Orang (JPO). 


\subsection{Penentuan fasilitas penyeberangan orang}

Pada penentuan fasilitas penyebrangan yang sesuai dengan volume kendaraan (V) dan volume penyebrang pejalan kaki (P) dapat ditentukan berdasarkan pedoman "Tata Cara Perencanaan Fasilitas Pejalan kaki di Kawasan Perkotaan DPU 011/T/Bt/1995 Tahun 1995" pada Tabel 1 dari survei ini akan diketahui apakah JPO sudah layak untuk dibangun atau hanya perlu fasilitas penyebrangan sebidang seperti zebra cross atau pelican cross. Adapun survei yang dilakukan yaitu mencatat volume kendaraan dan volume penyebrang pada form survei.

Adapun penggunan rumus untuk menentukan fasilitas penyeberangan sebagai berikut :

$$
\text { P. } V^{2}
$$

Keterangan :

$\mathrm{P}=$ Volume penyebrang pejalan kaki (orng/jam)

$\mathrm{V}=$ Volume kendaraan $(\mathrm{Kend} / \mathrm{jam})$

Tabel 2 Pemilihan fasilitas penyebrangan sebidang

\begin{tabular}{ccccc}
\hline No. & $\mathbf{P V}^{\mathbf{2}}$ & $\mathbf{P}$ & $\mathbf{V}$ & Rekomendasi awal \\
\hline 1. & $>10^{8}$ & $50-100$ & $300-500$ & Zebra cross $(\mathrm{Zc})$ \\
2. & $>2 \times 10^{8}$ & $50-1100$ & $400-750$ & Zc dengan lapak tunggu \\
3. & $>10^{8}$ & $50-1100$ & $>500$ & Pelikan (P) \\
4. & $>10^{8}$ & $>1100$ & $>500$ & Pelikan (P) \\
5. & $>2 \times 10^{8}$ & $50-1100$ & $>700$ & Pelikan dengan lapak tunggu \\
6. & $>2 \times 10^{8}$ & $>1100$ & $>400$ & Pelikan dengan lapak tunggu \\
\hline
\end{tabular}

Sumber : Bina marga , 1995.

\subsection{Kesesuaian fasilitas jembatan penyeberangan orang}

Dalam survei ini, peneliti melakukan pengukuran dimensi dari JPO yang berada di Jl. Yos Sudarso di depan Grand Tarakan Mall (GTM) untuk mengetahui apakah pembangunan JPO sudah dibangun sesuai dengan peraturan Tata Cara Perencanaan Jembatan Penyeberangan Untuk Pejalan Kaki di Perkotaan No. 027/T/Bt/1995 Tahun 1995.

Tabel 3 Peraturan pembanguan JPO.

\begin{tabular}{ccc}
\hline No. & Pemeriksaan & Standard \\
\hline 1. & Tinggi anak tangga & $15-21.5 \mathrm{~cm}$ \\
2. & Lebar minimum pejalan kaki & $2 \mathrm{~m}$ \\
3. & Tinggi sandaran anak tangga & $1.35 \mathrm{~m}$ \\
4. & Panjang jembatan & $>40 \mathrm{~m}$ dipasang pelindung panas \\
5. & Letak anak tangga jpo & Diluar trotoar \\
6. & Lebar injakan anak tangga & $21.5-30.5 \mathrm{~m}$ \\
7. & Apabila ada pilar ditengah & Diletakkan di median \\
8 & Tinggi ruang bebas tidak dilalui bis tingkat & $4.6 \mathrm{~m}$ \\
\hline
\end{tabular}

Sumber : Bina marga , 1995.

\subsection{Uji Validitas Dan Uji Realibitas}

Uji validitas dilakukan untuk mengetahui apakah butir-butir pertanyaan yang terdapat dalam kuesioner yang digunakan sebagai alat pengumpul data betul-betul valid dan mampu mengukur konsep yang akan diukur dalam penelitian ini. Uji validitas akan dilakukan dengan metode Product Moment, yaitu dengan mengkorelasikan skor butir pada kuesioner dengan skor totalnya. Jika nilai koefisien korelasinya lebih dari 0,3 maka butir pertanyaan tersebut dikatakan valid, dan jika nilai koefisien korelasinya kurang dari 0,3 maka butir pertanyaan tersebut dinyatakan tidak valid.Sedangkan pada uji reliabilitas dilakukan untuk mengetahui apakah butir-butir pertanyaan yang 
terdapat dalam kuesioner yang digunakan sebagai alat pengumpul data betul betul reliabel dalam arti bahwa alat pengumpul data tersebut tetap konsisten untuk mengukur suatu gejala yang sama dari beberapa responden koefisien reliabilitas berkisar antara 0.00-1.00. Dalam penelitian ini menggunakan metode alpha cronbach menggunakan program SPSS . Kuisioner dikatakan reliabel jika $\mathrm{r}$ hasil lebih besar dari $\mathrm{r}$ Tabel ( $\mathrm{r}$ hasil $>\mathrm{r}$ Tabel), dengan $\mathrm{r}$ Tabel minimal 0.3. Semakin besar nilai alpha Cronbach, maka semakin tinggi tingkat reliabilitas penelitian yang dilakukan.

\subsection{Importance-Perfomance Analysis (IPA)}

Dalam teknik ini responden diminta untuk merangking berbagai atribut atau elemen dari penawaran berdasarkan derajat pentingnya setiap atribut tersebut. Selain itu responden juga diminta merangking seberapa baik kinerja perusahaan dalam masing-masing atribut tersebut. Model ini menjelaskan konsep tentang loyalty pelanggan. Dari model ini dapat diketahui ada dua variabel utama yang menentukan kepuasan pelanggan yaitu expectation dan perceived performance. Expectation adalah harapan pelanggan terhadap produk yang diinginkan. Harapan ini dipengaruhi kebutuhan pribadi, pengalaman masa lalu, rekomendasi dari mulut ke mulut dan iklan. Sementara perceived performance adalah persepsi pelanggan terhadap penampilan, kinerja dari produk/produsen. Rumus untuk mengetahui tingkat kesesuaian adalah :

$$
T_{k i}=\frac{X i}{Y i} \times 100 \%
$$

Keterangan :

Tki

$\mathrm{Xi} \quad$ : Skor Penilaian Kinerja (Performance)

$\mathrm{Yi} \quad$ : Skor Penilaian Kepentingan (Importance)

\section{Hasil dan Pembahasan}

\subsection{Kondisi jembatan penyeberangan jalan raya yos sudarso}

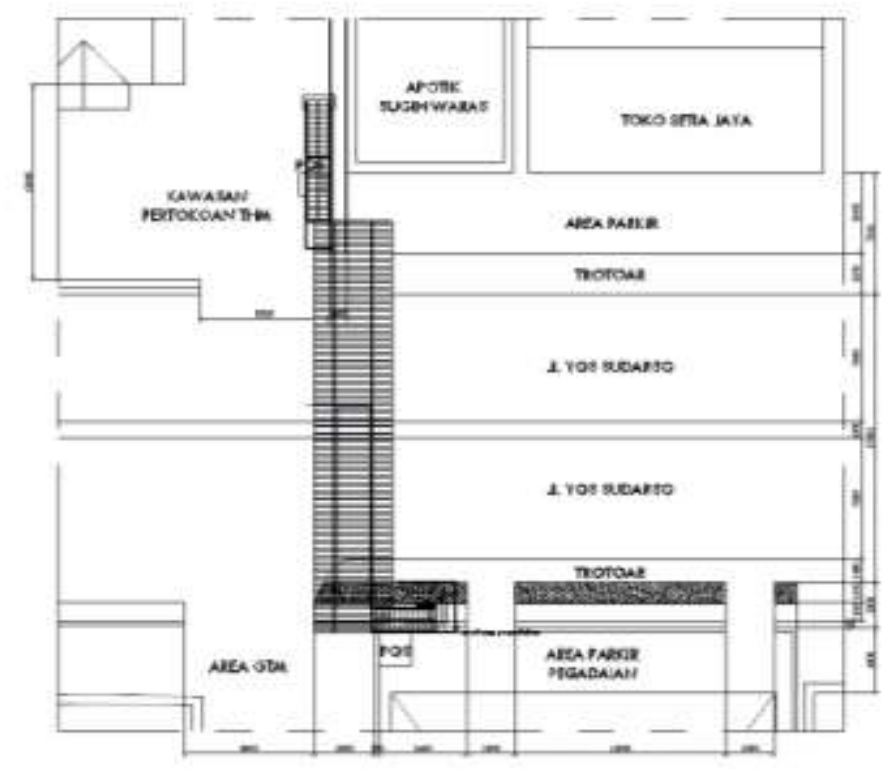

\section{Gambar 1 denah lokasi JPO}

Terlihat pada Gambar denah lokasi Jembatan Penyebrangan Orang di Kota Tarakan yang terletak di jalan raya Yos Sudarso dengan lokasi di depan Grand Tarakan Mall (GTM) terhubung ke kawasan 
pertokoan THM. Pembangunan jembatan penyeberangan ini di peruntukkan bagi masyarakat pejalan kaki yang memiliki hak dan kewajiban dan dilindungi berdasarkan Undang-Undang Republik Indonesia Nomor 22 Tahun 2009 Tentang Lalu Lintas Dan Angkutan Jalan pasal 1 Bagian Keenam Hak dan Kewajiban Pejalan Kaki dalam Berlalu Lintas.

\subsection{Kesesuaian fasilitas penyeberangan}

Untuk mengetahui fasilitas penyeberangan yang sesuai dengan lokasi studi dilakukan penelitian yaitu perhitugan volume kendaraan dan volume penyeberang jalan serta mengukur jembatan penyeberangan yang telah dibangun. Analisis datanya sebagai berikut :

Tabel 4 Data perhitungan PV

\begin{tabular}{|c|c|c|c|c|c|}
\hline \multirow{2}{*}{$\begin{array}{c}\text { Hari } \\
\text { Senin }\end{array}$} & \multirow{2}{*}{$\begin{array}{c}\text { waktu } \\
06.00-07.00\end{array}$} & \multirow{2}{*}{$\begin{array}{c}\begin{array}{c}\text { Kendaraan }(\mathbf{V}) \\
\text { Kend/jam }\end{array} \\
3696\end{array}$} & \multirow{2}{*}{$\begin{array}{c}\begin{array}{c}\text { Pejalan Kaki (P) } \\
\text { Org/jam }\end{array} \\
31\end{array}$} & \multicolumn{2}{|c|}{$\begin{array}{c}\text { P V } 6 \text { jam } \\
\text { tersibuk }\end{array}$} \\
\hline & & & & $\mathrm{P}=$ & 504 \\
\hline & $07.00-08.00$ & 6458 & 57 & & \\
\hline & $11.00-12.00$ & 6551 & 104 & $\mathrm{~V}=$ & 34994 \\
\hline & $12.00-13.00$ & 6488 & 162 & & \\
\hline & $15.00-16.00$ & 5336 & 84 & & \\
\hline & $16.00-17.00$ & 6465 & 66 & & \\
\hline \multirow[t]{6}{*}{ Selasa } & $06.00-07.00$ & 3010 & 13 & $\mathrm{P}=$ & 340 \\
\hline & $07.00-08.00$ & 5997 & 29 & & \\
\hline & $11.00-12.00$ & 5990 & 52 & $\mathrm{~V}=$ & 33253 \\
\hline & $12.00-13.00$ & 6020 & 95 & & \\
\hline & $15.00-16.00$ & 5530 & 71 & & \\
\hline & $16.00-17.00$ & 6706 & 80 & & \\
\hline \multirow[t]{6}{*}{ Rabu } & $06.00-07.00$ & 2888 & 22 & $\mathrm{P}=$ & 417 \\
\hline & $07.00-08.00$ & 5297 & 47 & & \\
\hline & $11.00-12.00$ & 6050 & 63 & $\mathrm{~V}=$ & 31606 \\
\hline & $12.00-13.00$ & 5964 & 88 & & \\
\hline & $15.00-16.00$ & 5105 & 107 & & \\
\hline & $16.00-17.00$ & 6302 & 90 & & \\
\hline \multirow[t]{6}{*}{ Kamis } & $06.00-07.00$ & 2810 & 23 & $\mathrm{P}=$ & 400 \\
\hline & $07.00-08.00$ & 6537 & 32 & & \\
\hline & $11.00-12.00$ & 5916 & 81 & $\mathrm{~V}=$ & 32484 \\
\hline & $12.00-13.00$ & 6245 & 88 & & \\
\hline & $15.00-16.00$ & 4733 & 103 & & \\
\hline & $16.00-17.00$ & 6243 & 73 & & \\
\hline \multirow[t]{6}{*}{ Jumat } & $06.00-07.00$ & 3433 & 15 & $\mathrm{P}=$ & 435 \\
\hline & $07.00-08.00$ & 6652 & 54 & & \\
\hline & $11.00-12.00$ & 6138 & 136 & $\mathrm{~V}=$ & 30651 \\
\hline & $12.00-13.00$ & 3389 & 76 & & \\
\hline & $15.00-16.00$ & 4479 & 62 & & \\
\hline & $16.00-17.00$ & 6560 & 92 & & \\
\hline \multirow[t]{6}{*}{ Sabtu } & $06.00-07.00$ & 2723 & 34 & $\mathrm{P}=$ & 370 \\
\hline & $07.00-08.00$ & 5633 & 44 & & \\
\hline & $11.00-12.00$ & 5926 & 97 & $\mathrm{~V}=$ & 30000 \\
\hline & $12.00-13.00$ & 5991 & 64 & & \\
\hline & $15.00-16.00$ & 4223 & 67 & & \\
\hline & $16.00-17.00$ & 5504 & 64 & & \\
\hline \multirow{6}{*}{ Minggu } & $06.00-07.00$ & 1709 & 13 & $\mathrm{P}=$ & 297 \\
\hline & $07.00-08.00$ & 3305 & 24 & & \\
\hline & $11.00-12.00$ & 4593 & 59 & $\mathrm{~V}=$ & 22323 \\
\hline & $12.00-13.00$ & 4275 & 62 & & \\
\hline & $15.00-16.00$ & 3624 & 43 & & \\
\hline & $16.00-17.00$ & 4817 & 96 & & \\
\hline
\end{tabular}


Untuk penentuan fasilitas penyeberangan di ambil pada jam tersibuk yaitu selama 6 jam penelitian dan dijumlakan selama 7 hari penelitian tersebut, dan akan di rata - ratakan pada jumlah waktu pengambilan data dalam satuan jam yaitu selama 42 jam tehitung dalam 7 hari pelaksanaan penelitian, seperti berikut ini :

P rata-rata $=\frac{\sum \text { Volume pejalan kaki }}{\sum \text { jam tersibuk pengambilan data }}=\frac{2763}{42}=65.79=66 \mathrm{org} / \mathrm{jam}$

V rata-rata $=\frac{\sum \text { Volume kendaraan }}{\sum \text { jam tersibuk pengambilan data }}=\frac{215311}{42}=5126.45=5126 \mathrm{kend} / \mathrm{jam}$

Selanjutnyaa perhitungan menggunakan rumus $\mathrm{P} . \mathrm{V}^{2}$ untuk menentukan fasilitas penyeberangan berdasarkan volume kendaraan dan volume pejalan kaki penyeberang jalan dihitung dengan menggunakan nilai rata-rata volume pejalan kaki $(\mathrm{P})$ dan volume kendaraan $(\mathrm{V})$, sebagai berikut :

$$
\begin{aligned}
\mathrm{P} . \mathrm{V}^{2} & =66 \times(5126)^{2} \\
& =66 \times 26280514 \\
& =1728882386.2>2 \times 10^{8}
\end{aligned}
$$

Dengan menghitung menggunakan rumus P. $V^{2}$ yaitu perhitungan $\mathrm{P}$ rata-rata 66 orang/jam dikalikan dengan V rata-rata 5126 kendaran/jam didapatkan hasil perhitungan $\mathrm{PV}^{2}$ 1728882386.2. Sesuai dengan kriteria untuk lokasi jalan Raya Yos Sudarso, jenis penyeberangan yang diperlukan sesuai rekomendasi Tata Cara Perencanaan Fasilitas Pejalan Kaki di Kawasan Perkotaan adalah penyeberangan sebidang yaitu pelican dengan pelindung atau Pelican Crossing dengan lapak tunggu yang memiliki kriteria jumlah $\mathrm{P}=50-1100$ orang/jam, $\mathrm{V}>700 \mathrm{kend} / \mathrm{jam}$ dan nilai $\mathrm{PV}^{2}>2 \times 10^{8}$, Sedangkan fasilitas penyeberangan tidak sebidang pada Departemental Advice Note TA/10/80 dalam Idris Zilhaldi (2007) yaitu Jembatan Penyeberangan membutuhkan jumlah $\mathrm{P}=100-1250$ orang/jam dengan $\mathrm{V}>7000$.

\subsection{Kesesuaian jembatan penyeberangan orang}

Dari hasil survei lapangan didapatkan data konstruksi Jembatan yang akan dibandingkan dengan persyaratan desain standar khusus untuk jembatan penyeberangan, sehingga dapat terlihat konstruksi jembatan penyeberangan sudah sesuai dengan peraturan Tata Cara Perencanaan Jembatan

\begin{tabular}{|c|c|c|c|c|}
\hline No. & Parameter pemeriksaan & Standard & Kondisi eksisting & Keterangan \\
\hline 1. & Tinggi anak tangga & $15-21.5 \mathrm{~cm}$ & $(18-20 \mathrm{~cm})$ & Sesuai dengan persyaratan \\
\hline 2. & $\begin{array}{l}\text { Lebar minimum pejalan } \\
\text { kaki }\end{array}$ & $2 \mathrm{~m}$ & $(2.4 \mathrm{~m})$ & Sesuai dengan Persyaratan \\
\hline 3. & $\begin{array}{c}\text { Tinggi sandaran anak } \\
\text { tangga }\end{array}$ & $1.35 \mathrm{~m}$ & $(1.15-1.20 \mathrm{~m})$ & $\begin{array}{c}\text { Tidak Sesuai dengan } \\
\text { Persyaratan }\end{array}$ \\
\hline 4. & Panjang jembatan & $\begin{array}{l}>40 \mathrm{~m} \text { dipasang } \\
\text { pelindung panas }\end{array}$ & $\begin{array}{l}(24 \mathrm{~m}) \text { dipasang } \\
\text { pelindung panas }\end{array}$ & Sesuai dengan Persyaratan \\
\hline 5. & Letak anak tangga jpo & Diluar trotoar & Diluar trotoar & Sesuai dengan Persyaratan \\
\hline 6. & Lebar injakan anak tangga & $21.5-30.5 \mathrm{~cm}$ & $(23-28 \mathrm{~cm})$ & Sesuai dengan Persyaratan \\
\hline 7. & Apabila ada pilar ditengah & $\begin{array}{l}\text { Diletakkan di } \\
\text { median }\end{array}$ & $\begin{array}{l}\text { Diletakkan di } \\
\text { median }\end{array}$ & Sesuai dengan Persyaratan \\
\hline 8. & $\begin{array}{l}\text { Tinggi ruang bebas tidak } \\
\text { dilalui bis tingkat }\end{array}$ & $4.6 \mathrm{~m}$ & $(5.4 \mathrm{~m})$ & Sesuai dengan Persyaratan \\
\hline
\end{tabular}
Penyeberangan Untuk Pejalan Kaki di Perkotaan, Sebagai Berikut :

Tabel 5 Parameter hasil pemeriksaan JPO

parameter hasil pemeriksaan JPO dapat disimpulkan bahwa dari 8 parameter yang dijadikan bahan penelitian ada satu yang tidak dapat dikatakan sesuai dengan persyaratan Tata Cara Perencanaan 
Jembatan Penyeberangan Untuk Pejalan Kaki di Perkotaan No. 027/T/Bt/1995 Tahun 1995 yaitu pada standar pembangunan tinggi sandaran anak tangga yang ditentukan 1.35 meter terhitung mulai dari permukaan lantai sampai dengan tepi atas sandaran tetapi pada kenyataan pengukuran peneliti didapatkan tinggi sandaran anak tangga hanya berukuran $1.15-1.20$ meter.

\subsection{Pengolahan data kuisioner}

\section{Populasi dan sampel}

Untuk menentukan populasi dalam penelitian ini dengan cara menghitung berapa banyak pengguna dari Jembatan Penyeberangan Orang selama 1 minggu dilakukan selama 6 jam sehari dan akan di ambil populasi terbanyak, didapatkan populasi terbanyak penggunaan JPO di hari senin yaitu 406 orang dan akan di sajikan di Tabel 4.5 sebagai berikut :

Tabel 6 Volume pengguna JPO

\begin{tabular}{cc}
\hline Waktu & Pejalan kaki menggunakan JPO \\
\hline Senin & 406 \\
Selasa & 225 \\
Rabu & 263 \\
Kamis & 276 \\
Jumat & 315 \\
Sabtu & 239 \\
Minggu & 176 \\
\hline
\end{tabular}

Dari Tabel 6 dapat dihitung jumlah sampel yang diperlukan dalam melakukan pembagian kuisioner menggunakan rumus Slovin sebagai berikut :

$$
\mathrm{n}=\frac{\mathrm{N}}{\mathrm{Nx} \mathrm{E}^{2}+1}=\frac{406}{406 \times(0.1)^{2}+1}=\frac{406}{5.06}=80.23=80 \text { sampel }
$$

Pada perhitungan di atas menggunakan rumus Slovin didapatkan jumlah sampel sebesar 80 sampel.

\section{Uji validitas}

Tabel 7 hasil uji validitas

\begin{tabular}{cccccc}
\hline $\begin{array}{c}\text { Atribut } \\
\text { kepuasan }\end{array}$ & $\begin{array}{c}\text { Corrected item-total } \\
\text { correlation }\end{array}$ & Keterangan & $\begin{array}{c}\text { Atribut } \\
\text { Kepentingan }\end{array}$ & $\begin{array}{c}\text { Corrected item-total } \\
\text { correlation }\end{array}$ & Keterangan \\
\hline A1 & .566 & Valid & B1 & .641 & .677 \\
A2 & .538 & Valid & B2 & .480 & Valid \\
A3 & .628 & Valid & B3 & .654 & Valid \\
A4 & .478 & Valid & B4 & .618 & Valid \\
A5 & .520 & Valid & B5 & .668 & Valid \\
A6 & .596 & Valid & B6 & .719 & Valid \\
A7 & .597 & Valid & B7 & .704 & Valid \\
A8 & .670 & Valid & B8 & .562 & Valid \\
A9 & .450 & Valid & B9 & .713 & Valid \\
A10 & .648 & Valid & B10 & .674 & Valid \\
A11 & .617 & Valid & B11 & .677 & Valid \\
A12 & .651 & Valid & B12 & .680 & Valid \\
A13 & .621 & Valid & B13 & .690 & Valid \\
A14 & .762 & Valid & B14 & .719 & Valid \\
A15 & .685 & Valid & B15 & & \\
\hline
\end{tabular}


Uji ini dilakukan dengan cara membandingkan $r$ hitung dengan $r$ tabel, jika $r$ hitung $>r$ tabel yaitu 0.2 yang didapatkan dari tabel produk momen, maka item dikatakan valid. berikut tabel yang disajikan dan diolah menggunakan aplikasi SPSS :

\section{Uji reliabilitas}

Reliabel dalam arti bahwa alat pengumpul data tersebut tetap konsisten untuk mengukur suatu gejala yang sama dari beberapa responden koefisien reliabilitas berkisar antara 0.00-1.00, hasil uji reliabilitas disajikan pada tabel sebagai berikut :

Tabel 8 Hasil uji reliabilitas

\begin{tabular}{ccc}
\hline Atribut & \multicolumn{2}{c}{ Reliability statistics } \\
& Cronbach's alpha & N of items \\
\hline Kepuasan & .871 & 15 \\
Kepentingan & .901 & 15 \\
\hline
\end{tabular}

\subsection{Tingkat kinerja JPO}

Untuk mengetahui tingkat kinerja dari fasilitas jembatan penyeberangan orang dilakukan perhitungan volume penyeberang jalan dan melakukan penyeberan kuisioner, sebagai berikut :

\section{Berdasarkan pengguna JPO}

Perhitungan tingkat pemanfaatan JPO menggunakan rumus sederhana untuk mengetahui persentase tingkat pemanfaatan pada Jembatan Penyeberangan Orang dan menggunakan hasil perhitungan ratarata pengguna JPO, sebagai berikut :

$$
\begin{aligned}
\text { Prosentase } & =\frac{\mathrm{A}}{(\mathrm{A}+\mathrm{B})} \times 100 \% \\
& =\frac{271.43}{(271.43+123.29)} \times 100=0.687 \times 100=68.77 \%
\end{aligned}
$$

Sedangkan untuk mengetahui tingkat persentase yang tidak menggunakan Jembatan Penyeberangan Orang (JPO) sebagai berikut :

$$
\begin{aligned}
\text { Prosentase } & =\frac{\mathrm{B}}{(\mathrm{B}+\mathrm{A})} \times 100 \% \\
& =\frac{123.29}{(123.29+271.43)} \times 100=0.3123 \times 100=31.23 \%
\end{aligned}
$$

Tabel 9 Tingkat pemanfaatan JPO.

\begin{tabular}{ccc}
\hline Hari & Menggunakan JPO (A) & Tidak Menggunakan JPO(B) \\
\hline Senin & 406 & 98 \\
Selasa & 225 & 115 \\
Rabu & 263 & 154 \\
Kamis & 276 & 124 \\
Jumat & 315 & 120 \\
Sabtu & 239 & 131 \\
Minggu & 176 & 121 \\
Rata -Rata & 271.43 & 123.29 \\
Persentase & $68.77 \%$ & $31.23 \%$ \\
\hline Tingkat Pemanfaatan & \multicolumn{3}{c}{ BERMANFAAT } \\
\hline
\end{tabular}


Persentase perhitungan tingkat pemanfaatan Jembatan Penyeberangan Orang yaitu sebesar $68.77 \%$ dan dapat dikatakan tingkat pemanfaatannya adalah bermanfaat.

\section{Berdasarkan Hasil Kuisioner Metode IPA (Importance Performance Analysis)}

Analisa Immportance-Performance Analysis (IPA) ditujukan kepada responden berdasarkan pengguna JPO. berikut adalah hasil dari analisa IPA :

$$
\begin{aligned}
T k i & =\frac{\sum X i}{\sum Y i} \times 100 \% \\
& =\frac{4451}{5151} \times 100 \% \\
& =89,41 \%
\end{aligned}
$$

Hasil dari total keseluruhan harapan dan kinerja dari pengguna jasa adalah $89.41 \%$.

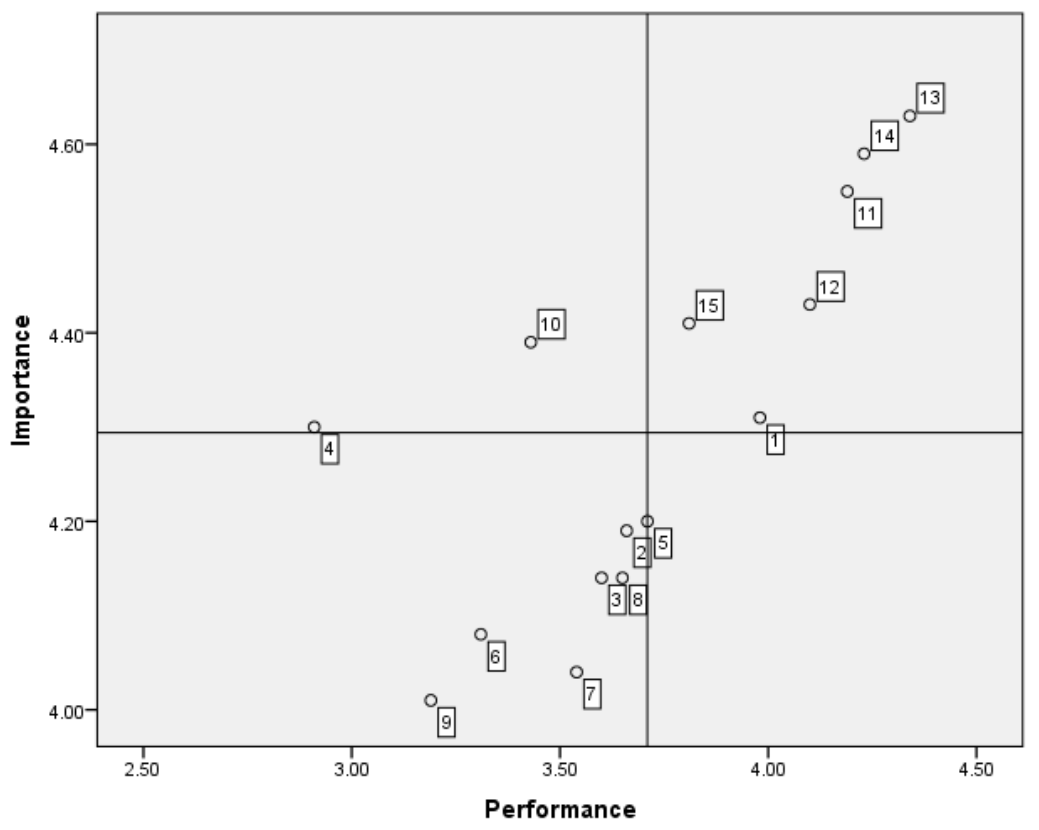

Gambar 2 Diagram Kartesius Immportance-Performance Analysis

Untuk tingkat kepuasan dari penggunaan Jembatan Penyeberangan Orang di depan Grand Tarakan Mall, berikut ini akan dibahas pada setiap kuadran :

\section{Kuadran 1 (Prioritas Utama)}

Atribut-atribut yang berada pada kuadran ini dianggap sangat penting oleh pelanggan/ pengguna JPO tetapi pelayanannya tidak memuaskan. Atribut-atribut ini prioritas utama untuk segera dilakukan perbaikan oleh perusahaan.

Atribut $4 \quad$ : Mudah di akses oleh penyandang disabilitas.

Atribut 10 : Kebersihan Fasilitas Jembatan Penyebrangan Orang.

Kuadran 1 yang memuat faktor-faktor yang dianggap penting oleh pelanggan tetapi pada kenyataannya faktor-faktor ini belum sesuai seperti yang di harapkan (kenyataan yang diperoleh masih sangat rendah). Variabel-variabel yang masuk dalam kuadran ini harus ditingkatkan dengan cara perusahaan tetap berkonsentrasi pada kuadran ini. 
2. Kuadran 2 (Pertahankan)

Atribut-atribut yang berada pada kuadran ini dianggap sangat penting oleh pelanggan dan kinerja pelayanannya sangat memuaskan.

Atribut 1 : Jarak sangat dekat dengan pusat perbelanjaan.

Aribut 11 : Tidak mengganggu arus lalu lintas.

Atribut 12 : Tidak menggangu aktivitas Perdagangan.

Atribut 13 : Meningkatkan keselamatan bagi pejalan kaki.

Atribut 14 : Tinggi sandaran Jembatan meningkatkan keselamatan bagi pengguna.

Atribut 15 : Penerangan pada Jembatan Penyebrangan Orang.

Kuadran 2 yang memuat faktor-faktor yang dianggap oleh pelanggan sudah sesuai dengan yang diharapkannya. Variabel-variabel yang termasuk dalam kuadran ini harus tetap dipertahankan, karena variabel ini yang menjadikan JPO tersebut memiliki keunggulan di mata pengguna.

3. Kuadran 3 (Prioritas Rendah)

Atribut-atribut pada kuadran ini dianggap tidak terlalu penting oleh pelanggan dan pelayanannya kurang memuaskan.

Atribut $2 \quad$ : Jarak sangat dekat dengan pemberhentian transportasi umum.

Atribut 3 : Jarak dari atau ke pusat kegiatan (sekolah, kantor, kampus, tempat ibadah, dll..)

Atribut 6 : Ukuran tangga tidak membuat pengguna kelelahan.

Atribut $7 \quad$ : Bentuk dan model Jembatan Penyebrangan Orang membuat ketertarikan bagi para pengguna.

Atribut 8 : Posisi penempatan Jembatan Penyebrangan orang menambah keindahan kota.

Atribut 9 : Perlu adanya ruang hijau pada fasilitas Jembatan PenyebranganOrang.

Kuadran 3 pada variable diatas dianggap kurang berpengaruh terhadap kepuasaan pengguna namun pelaksanaan dilapangan harus tetap diperhatikan sesuai dengan tingkat kebutuhan dan kepentingan dari ketersediaan pelayanan itu sendiri. Karena jika tidak diperhatikan dan kinerjanya memburuk maka akan dapat berpengaruh pada keseluruhan pelayanan yang diberikan.

4. Kuadran 4 (Berlebihan)

Pada hasil pengolahan diagram kartesius tidak terdapat atribut yang termasuk dalam kuadran 4 , tetapi perlu diketahui atribut-atribut yang berada pada kuadran ini dianggap tidak terlalu penting oleh pelanggan tetapi pelayanannya memuaskan.Variabel-variabel yang termasuk dalam kuadran ini dapat dipertimbangkan untuk dikurangi, sehingga perusahaan dapat menghemat biaya.

\section{Kesimpulan}

Dari hasil penelitian yang berjudul Studi Analisis Fasilitas Jembatan Penyeberangan Orang di Kota Tarakan (Studi Kasus : Jl. Yos Sudarso Depan Grand Tarakan Mall Kota Tarakan). Dapat disimpulkan bahwa fasilitas yang sesuai pada lokasi penelitian adalah Pelican Crossing dengan lapak tunggu berdasarkan tabel penentuan fasilitas penyeberangan, satu parameter tidak sesuai standar perencanaan yaitu tinggi sandaran anak tangga 1.35 meter dan ukuran dilapangan $1.15-1.20$ meter, dan tingkat kinerja JPO adalah bermanfaat, dengan persentase penyeberang pejalan kaki menggunakan JPO $68.77 \%$. 


\section{Daftar Pustaka}

Direktorat Jendral Bina Marga (1995), Tata Cara Perencanaan Jembatan Penyeberangan Untuk Pejalan Kaki di Perkotaan, Departemen Pekerjaan Umum, Jakarta.

Direktorat Jenderal Bina Marga (1995), Tatacara Perencanaan Fasilitas Pejalan Kaki di Kawasan Perkotaan, Jakarta.

Idris, Zihardi. (2007), “Jembatan Penyeberangan Di Depan Kampus UMS Sebagai Fasilitas Pejalan Kaki”, Universitas Muhammadiyah, Surakarta, Dinamika TEKNIK SIPIL, Vol. 7, No 1.

Mashuri dan Widodo S., (2012), "Tingkat Pemanfaatan Dan Faktor Faktor Yang Mempengaruhi Pemakaian Jembatan Penyeberangan Orang Di Depan Mall Tatura Kota Palu”.Palu,"MEKTEK”. No. 1.

Pranata, G.I., (2017), Evaluasi Efektivitas Dan Kelayakan Teknis Jembatan Penyeberangan Orang (Jpo) Di Cbd Kota Bandar Lampung, Tesis., Universitas Lampung, Bandar Lampung.

Undang-Undang Nomor 22 Tahun 2009 Tentang Lalu Lintas Dan Angkutan Jalan. 